\title{
Relationship among Apis mellifera L. stings, swarming and climate conditions in the city of Rio Claro, SP, Brazil
}

\author{
Pereira AM (1), Chaud-Netto J (2), Bueno OC (1), Arruda VM (2)
}

(1) Social Insects Study Center, Rio Claro Biosciences Institute, São Paulo State University (UNESP - Univ Estadual Paulista), Rio Claro, São Paulo State, Brazil; (2) Department of Biology, Rio Claro Biosciences Institute, São Paulo State University (UNESP - Univ Estadual Paulista), Rio Claro, São Paulo State, Brazil.

\begin{abstract}
The presence of bees (Apis mellifera L.) in urban areas has increased in recent years due to environmental disturbances caused by humans. Bee migration to cities may provoke serious accidents, since some people present allergic reactions to their venoms. In Rio Claro city, São Paulo state, Brazil, the number of calls to the fire brigade for removal of bee swarms, and the number admissions in local hospitals due to bee stings were investigated during 2002 and 2003, and a correlation between these data and the average temperature, rainfall and relative humidity was found. The study period was divided into three phases according to the number of times that the fire brigade was called to remove swarms (263 times): January to July $2002-51$ calls (19.39\%); August 2002 to July $2003-140$ calls (53.23\%); and August to December $2003-72$ calls (27.38\%). A significant correlation among the number of calls, the local temperature and rainfall was detected. The number of accidents was not associated with environmental variables. Based on the current results, public activities for prevention of bee attacks may be developed to avoid unwanted contact between humans and these insects, and/or provide the appropriate management of the colonies.
\end{abstract}

Key words: synanthropism, reproductive swarms, absconding, environmental variables, honeybees.

In 1956, in order to improve the conditions for beekeeping in Brazil, and especially the honey production, the Brazilian researcher Warwick Estevam Kerr brought 51 Apis mellifera queens from Tanzania and South Africa to the country. These African bees would presumably be better adapted to tropical conditions in Brazil than the European bees existing here (1). In the following year, 26 African swarms escaped from the forest of Camaquan (14 km from Rio Claro, SP) and rapidly spread, hybridizing with European bees. The bees originated from this mixture were known as Africanized bees, a polyhybrid resultant from crosses between African bees (Apis mellifera scutellata) and the European subspecies Apis mellifera ligustica, Apis mellifera mellifera, Apis mellifera caucasica and Apis mellifera carnica (2).
Africanized honeybees are widely known for their high productivity, but are also notorious for their great defensiveness and rapid attacks against invaders (3). According to Gonçalves et al. (4), these bees are quicker and more efficient in food supplying, especially when compared with German bees (A. m. mellifera). They are also capable of fast recruiting other workers to attack possible intruders $(5,6)$.

In Brazil, one of the consequences of the destruction of green areas around cities is the frequent migration of this social insect to urban areas. Their colonies are installed in houses, walls and trees, which indicates a high degree of synanthropism (7). Hence, the number of accidents caused by bee stings has increased in recent years (8-17). Escher et al. (18) and 
Malaspina et al. (19) reported a large number of patients treated in emergency centers in São Paulo state, affected by allergic reactions to Hymenoptera venom, and observed that 32\% of them were victims of bee stings, $37 \%$ of wasp stings and $31 \%$ of ant stings.

Concern about accidents is mainly connected with swarming frequency, which occurs three to four times a year, and the variety of shelters available in urban areas (20). Such refuges increase the contact between bees and humans. Accidents are associated with human activities where swarms are installed and surroundings areas, and may be worsened when people throw objects or spray chemicals on bees, or even attempt to inappropriately remove or destroy swarms (7).

According to Soares et al. (21), Africanized honeybees present two major models of dispersion. The first one, called "reproductive swarms", occurs when food supply is abundant and the bee population is increased. Under such condition, the colony produces a new queen and part of the bees, including the old queen, leaves the hive and look for a new nesting site. The second model, known as "absconding swarms", takes place when there is food shortage, unfavorable weather and/or threat of predation. In this case, all bees leave the hive and migrate to another place. In Brazil, the former model is more common between August and October, while the latter is more frequent between April and May.

Tropical bees exhibit swarming behavior more frequently when compared to bees from temperate regions (22). In French Guyana, Otis (23) found that a single colony of Africanized honeybees produces 6 to 12 swarms per year and, when the swarm production of offspring colonies is included, more than 60 colonies can be formed in a single year. In contrast, European honeybees produce 1 to 3.6 swarms a year during the months in which there is a high production of food resources $(24,25)$. This high productivity among Africanized bees may be attributed to differences between tropical and temperate habitats. While in temperate climates swarming episodes are limited in the winter because colonies have low food stocks and only a few adult workers; in the tropics, bees are free of such restrictions associated with low temperatures and may use their energy reserves for reproduction rather than storing honey (22).
In addition, Africanized bees are more likely to abscond than European bees. This situation occurs when the bees abandon the site where the colony is currently located and find a new nest. It differs from the reproductive swarm because few or no workers and no adults nor immature viable queens are left in the original hive $(22,26)$. This behavior is usually provoked by environmental disturbances (fire; predation; low temperature, excessive lighting or rainwater inside the nest) or a decrease in food sources (lack of nectar, pollen or water $)(26,27)$. In Brazil, about $79 \%$ of absconding cases occur during the wet season, a period marked by food shortage $(22,26,28)$.

The present study aimed to analyze the number of hospital admissions caused by insect stings in the city of Rio Claro, SP, Brazil, from 2002 to 2003, and the number of calls to the local fire brigade in order to remove swarms in urban areas, and check for significant correlations between these data and climate conditions recorded in the period.

In order to evaluate such information, the number of admissions in hospitals of Rio Claro provoked by insect stings between January 2002 and December 2003, and their regularity in this period, were evaluated. The frequency of calls to the fire brigade for removal of nests or nomad swarms in the urban area of Rio Claro was also recorded. Climatic data (average temperature, rainfall and relative humidity) were provided by the Center for Environmental Planning and Analysis (CEAPLA) of UNESP at Rio Claro, SP, Brazil. A multiple correlation (r) analysis among data concerning the number of reported accidents, the number of calls and the environmental variables was performed.

The period between 2002 and 2003 was divided into three phases according to the number of times that the fire brigade was activated to remove swarms (263 times). The first phase comprised the months from January to July 2002 with 51 calls (19.39\%); the interval from January to March was the most representative, with 35 calls (13.31\%). Rainfall had the higher rates in January and February (Figure 1), while the higher average temperature happened between January and April (Figure 2).

The second phase comprised the interval between August 2002 and July 2003 with 140 calls (53.23\%). From August to April, 121 calls (46.01\%) to the fire brigade were recorded. Rainfall rates were elevated from November 
Rainfall -----Number of calls

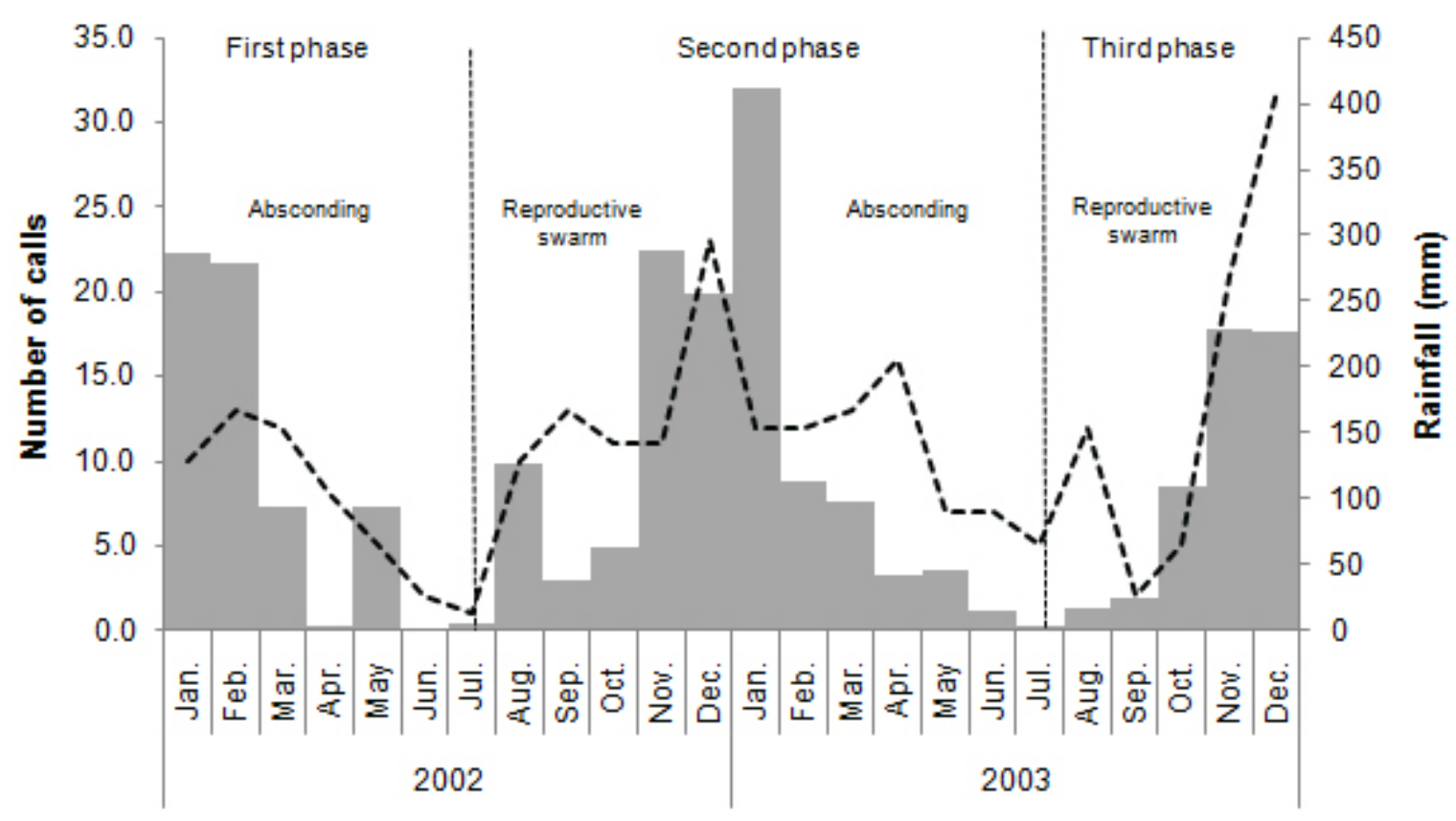

Figure 1. Number of calls to the Rio Claro fire brigade and average rainfall during 2002 and 2003.

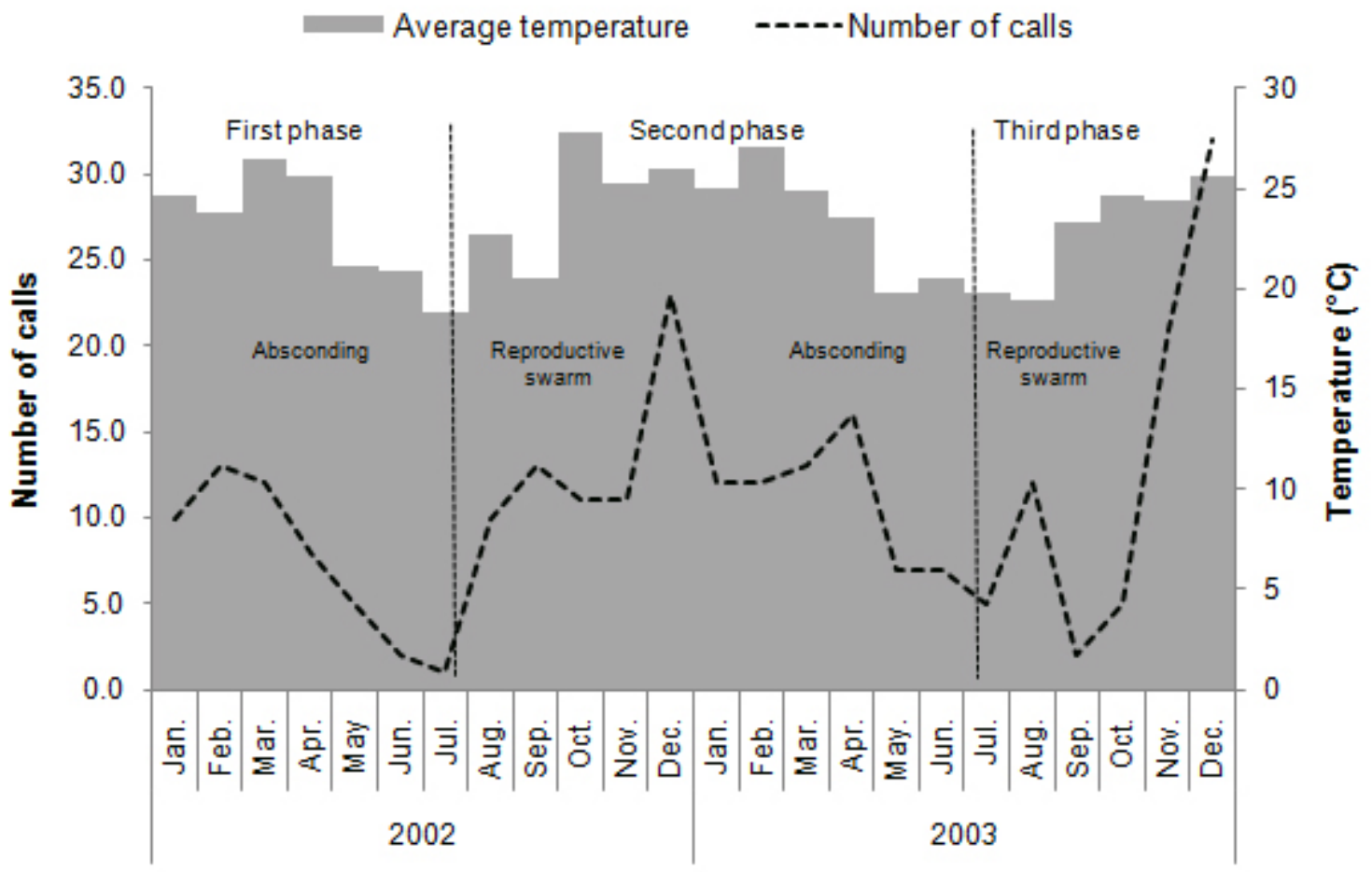

Figure 2. Number of calls to the Rio Claro fire brigade and average temperature during 2002 and 2003. 


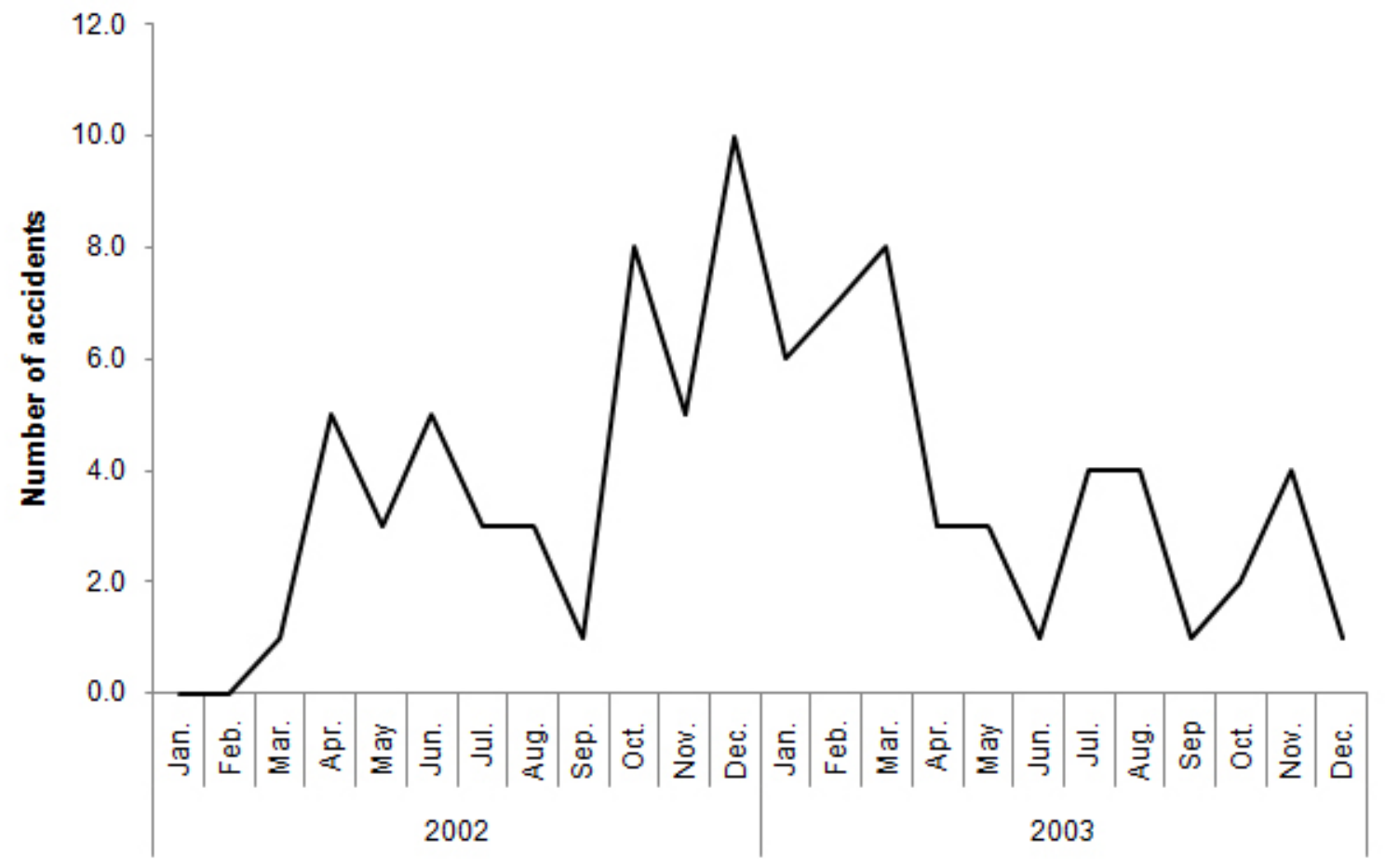

Figure 3. Number of admissions to hospitals due to accidents caused by insect stings during 2002 and 2003.

Table 1. Correlation between the number of calls and the number of accidents with climate conditions

\begin{tabular}{c|c|c|c}
\hline & Average temperature & Rainfall & Relative humidity \\
\hline Number of calls & $r=0.4790^{*}$ & $r=0.5273^{*}$ & $r=0.2714$ \\
\hline Number of accidents & $r=0.3548$ & $r=0.0920$ & $r=-0.0768$ \\
\hline
\end{tabular}

*significance level is $5 \%$.

to February (Figure 1) and temperatures were higher from October to April (Figure 2).

The third phase included the months from August to December 2003 with 72 calls (27.38\%), being August, November and December the most important, with 65 calls (24.71\%) (Figure 1). Rainfall was more intense in November and December (Figure 1) and the higher averages of temperature occurred from September to December (Figure 2).

Based on these data, it is possible to infer that the number of calls to the fire brigade was only associated with two environmental variables rainfall and temperature (Table 1).

The number of accidents recorded in emergency centers was also divided into three phases ( $n=88$ ): from March to August 2002, from October 2002 to April 2003, and from July to November 2003 (Figure 3). However, the incidence of accidents was not connected with environmental variables ( $p>0.05$; Table 1$)$.

The reproductive swarming, characterized by colony division, occurs when food supply is elevated and colony population is increased (21). In the region of Rio Claro, the augmented demand for food is provided by the flowering of Citrus sinensis (Rutaceae), a species much visited by honeybees. The importance of this plant for A. mellifera is evidenced by the great amount of its pollen in honey, particularly between August 
and October, in beehives in Rio Claro region (29-32). In São Paulo state, orange blossom starts after the first rainfalls of the second semester (more than $20 \mathrm{~mm}$ of rain) and usually takes place between August and October, which favors the reproductive swarming (33). Ribeiro et al. (34) found that low rainfall and the number of hours with low temperature are the main factors for the induction of Citrus blossom in cities near Rio Claro (Limeira and Piracicaba). Other plant families that provide nectar and pollen for honeybees in the region are: Leguminosae, Myrtaceae, Palmae, Rubiaceae, Asteraceae, Caesalpiniaceae, Fabaceae, and Mimosaceae (30).

Thus, increase in rainfall and temperature after July induces flowering of Citrus, which, in turn, creates resources that contribute to reproductive swarming observed in the first half of the second phase (from August to November) and also in the third phase (Figures 1 and 2). Soares et al. (21) described that reproductive swarming is more common between August and October in the Ribeirão Preto region. Rubink et al. (35) reported that $81 \%$ of the swarms captured in Texas and $67 \%$ of the swarms captured in Mexico occurred in April, a characteristic of bees from temperate climate, which is favored by the increase of food (24).

The absconding behavior, when all members of the colony move to another place, may be seen in the first phase and in the second half of the second phase (from December to July), and is provoked by high rates of rainfall during the hot season in Rio Claro (Figures 1 and 2). The heavy rainfall may decrease nectar production, contributing to nest abandonment. Several researchers also found a correlation between the migration behavior - as a consequence of reduced blossom - and increased rainfall $(22,26-$ 28). Nevertheless, Schneider and McNally (36) observed no clear connection between migration and environmental conditions. For them, such behavior is influenced mainly by intracolonial demographic interactions, such as storage of food and foraging patterns. In Ribeirão Preto region, Soares et al. (21) observed that absconding is more frequent from April to May.

On the other hand, the development of the colony is highly influenced by environmental conditions (37). Rainfall and temperature data presented a significant correlation with the number of calls to the fire brigade for removal of swarms between 2002 and 2003 (Table 1, Figures 1 and 2). With the decrease of green areas and natural shelters, the swarms that were formed in this period were forced to settle in cities, showing a high degree of synanthropism. An important association between the number of calls for swarm removal and temperature was observed by Mello et al. (7) in São Paulo city, Brazil.

Malerbo-Souza et al. (38) described that $49.9 \%$ of swarms captured in Jaboticabal city, São Paulo state, were housed in urban buildings, while $50.1 \%$ were found in local vegetation. On the other hand, in the city of São Paulo, Mello et al. (7) observed that $28.2 \%$ of nomad swarms (without the presence of brood combs and honey) were taken from trees, whereas $71.89 \%$ were removed from human constructions, including attics, basements, interior walls, light poles, inner boxes, switchboards and sewer inspection boxes. However, colonies (with the presence of combs with brood and honey) installed on trees comprised only $8.5 \%$ of the case, whereas $91.5 \%$ were colonies in buildings.

The number of accidents registered in hospitals was not significantly connected with any environmental variable (Table 1), which suggests that other variables - including wind speed, solar radiation and barometric pressure not analyzed in the present study may interfered in these data (39). Additionally, hospital records do not inform which insect (bee, wasp or ant) caused the accident and not every victim seeks medical care in such cases. However, the months when accidents are more frequent coincide with those with higher temperature means. Bees tend to perform more outside activities and be more defensive when temperature and luminous intensity are augmented, which increases the contact between humans and these insects (40, 41). Southwick and Moritiz (39) showed that 92.4\% of the defensive behavior in European honeybees can be explained by environmental variables, such as ambient temperature, relative humidity and wind speed.

Based on the current findings, we can conclude that in the city of Rio Claro the periods with higher number of calls to the fire brigade correspond to the two A. mellifera swarm terms reported by Soares et al. (21). The first one occurred from December to May and the second from August to December. During the first one, the cases of absconding were more frequent, since 
in the wet season, swarms leave their original nests and look for new places to establish their colonies. The second period was characterized by an increase in nectar and pollen production, probably influenced by Citrus blossom, although other plants - such as Vernonia, Baccharis, Bauhinia, Calliandra, Cassia, Caesalpinia and many species of Eucalytus - may also be flowered (42). The large amount of available food provokes the production of reproductive swarms, a natural division of colonies. With the reduction of natural refuges, swarms tend to migrate to cities and settle in urban shelters, which constitutes the source of accidents with humans. The knowledge of the period and frequency of the swarming behavior provides information for prevention of accidents due to unwanted contact between humans and bees, in the form, for example, of appropriate management of bee colonies.

\section{COPYRIGHT}

(C) CEVAP 2010

\section{SUBMISSION STATUS}

Received: April 7, 2010.

Accepted: July 14, 2010.

Abstract published online: August 13, 2010.

Full paper published online: November 30, 2010.

\section{CONFLICTS OF INTEREST}

There is no conflict.

\section{FINANCIAL SOURCE}

The National Council for Scientific and Technological Development (CNPq) provided the financial grant.

\section{CORRESPONDECE TO}

ANDRIGO MONROE PEREIRA, Centro de Estudos de Insetos Sociais, Instituto de Biociências de Rio Claro, UNESP, Av. 24A, 1515, Rio Claro, SP, 13.506-900, Brasil. Phone: + 551935264160 . Fax: + 55193534 8523. Email: andrigompereira@ yahoo.com.br.

\section{REFERENCES}

1. Kerr WE. The history of the introduction of African bees to Brazil. South Afric Bee J. 1967;39(2):3-5.

2. Stort AC, Gonçalves LS. A africanização das abelhas Apis mellifera nas Américas I. In: Barraviera B, editor. Venenos animais: uma visão integrada. Rio de Janeiro: EPUC; 1994. p. 33-47.

3. Pereira AM, Chaud-Netto J. Africanized honeybees: biological characteristics, urban nesting behavior and accidents caused in Brazilian cities (Hymenoptera: Apidae). Sociobiology. 2005;46(3):535-50.

4. Gonçalves LS, Kerr WE, Chaud-Netto J, Stort AC. Some comments on the final report of the committee on the African honeybee. National Research Council - N. A. S. Mimeographic paper. USA: Cornell University; 1972. 35 p.

5. Collins AM, Rinderer TE, Harbo JR, Bolten AB. Colony defense by Africanized and European honey bees. Science. 1982;218(4567):72-4.

6. Breed MD, Guzmán-Novoa E, Hunt GJ. Defensive behavior of honey bees: organization, genetics and comparisons with other bees. Annu Rev Entomol. 2004;49(1):271-98.

7. Mello MHSH, Silva EA, Natal D. Abelhas africanizadas em área metropolitana no Brasil: abrigos e influências climáticas. Rev Saúde Públ. 2003;37(2):237-41.

8. Winston ML. Killer bees: the Africanized honey bee in the Americas. Cambridge: Harvard University Press; 1992. 162 p.

9. Guzmán-Novoa E, Page Junior RE. Genetic dominance and worker interactions affect honeybee colony defense. Behav Ecol. 1994;5(1):91-7.

10. Diaz-Sanchez CL, Lifshitz-Guinzberg A, Ignacio-Ibarra G, Halabe-Cherem J, QuinonesGalvan A. Survival after massive (>2000) Africanized honeybee stings. Arch Intern Med. 1998;158(8):925-7.

11. de Oliveira FA, Guimarães JV, dos Reis MA, Teixeira V de P. Human accidents with stings of Africanized bees. Rev Soc Bras Med Trop. 2000;33(4):403-5.

12. Bresolin NL, Carvalho LC, Goes EC, Fernandes $\mathrm{R}$, Barotto AM. Acute renal failure following massive attack by Africanized bee stings. Pediatr Nephrol. 2002;17(8):625-7.

13. Daher E de F, da Silva Junior GB, Bezerra GP, Pontes LB, Martins AM, et al. Acute renal failure after massive honeybee stings. Rev Inst Med Trop São Paulo. 2003;45(1):45-50.

14. Gabriel DP, Rodrigues Junior AG, Barsante RC, dos Santos Silva V, Caramori JT, Martim LC, et al. Severe acute renal failure after massive attack of Africanized bees. Nephrol Dial Transplant. 2004;19(10):2680.

15. Azevedo RV, Paiva RB, Ades F, David CM. Síndrome de envenenamento por 2000 picadas de abelhas africanizadas. Rev Bras Ter Intensiva. 2006;18(1):99-103.

16. Betten DP, Richardson WH, Tong TC, Clark 
RF. Massive honey bee envenomation-induced rhabdomyolysis in an adolescent. Pediatrics. 2006;117(1):231-5.

17. Cristiano MP, Cardoso, DC. Honeybees and caterpillars: epidemiology of accidents involving these animals in the Criciúma region, southern Santa Catarina State, Brazil. J Venom Anim Toxins incl Trop Dis. 2008;14(4):719-24.

18. Escher SHG, Castro APBM, Croce J, Palma MS, Malaspina O, Palma MFM, et al. Estudo dos métodos laboratoriais utilizados no diagnóstico de alergia a Hymenoptera: análise crítica. Rev Bras Alerg Imunopatol. 2001;24(2):46-53.

19. Malaspina O, Bueno OC, Augusto AVL, Palma MS. Biologia dos himenópteros sociais. In: Castro FFM, Palma MS, editors. Alergia a venenos de insetos. Barueri: Manole; 2009. p. 5-36.

20. Diniz NM, Soares AEE, Pecci VB. Africanized honey bee control program in Ribeirão Preto city, São Paulo, Brazil. Am Bee J. 1994;134(11):746-8.

21. Soares AEE, Michelette ERF, Diniz NM, Teixeira MV. Dispersão das abelhas africanizadas nas Américas: aspectos comportamentais. In: Anais do X Congresso Brasileiro de Apicultura; 1994; Pousada do Rio Quente, GO, Brasil. v. 1. p. 204-11.

22. Winston ML. The biology and management of Africanized honey bees. Annu Rev Entomol. 1992;37(1):173-93.

23. Otis CW. Population biology of the Africanized honey bees. In: Spivak M, Fletcher DJC, Breed $\mathrm{M}$, editors. The "African" honey bee. Boulder CO: Westview Press; 1991. p. 198-218.

24. Winston ML. Swarming, afterswarming, and reproductive rate of unmanaged honeybee colonies (Apis mellifera). Insectes Sociaux. 1980;27(4):391-8.

25. Lee PC, Winston ML. Effects of reproductive timing and colony size on the survival, offspring colony size and drone production in the honey bee (Apis mellifera). Ecol Entomol. 1987;12(2):187-95.

26. Winston ML, Otis GW, Taylor OR. Absconding behaviour of the Africanized honeybee in South America. J Apicultural Res. 1979;18(2):85-94.

27. Fletcher DJC. The African bee, Apis mellifera adansonii in Africa. Annu Rev Entomol. 1978;23(1):151-71.

28. Chaud-Netto J. Abandono do ninho: uma estratégia de sobrevivência das abelhas do gênero Apis. In: Encontro Brasileiro sobre Biologia de Abelhas e outros Insetos Sociais; 1992; Rio ClaroRibeirão Preto, SP, Brasil. Naturalia. 1992. p. 101-5.

29. Carvalho CAL, Marchini LC, Ros PB. Fontes de pólen utilizadas por Apis mellifera L. e algumas espécies de Trigonini (Apidae) em Piracicaba (SP). Bragantia. 1999;58(1):49-56.
30. Marchini LC, Moreti ACCC, Teixeira EW, Silva ECA, Rodrigues RR, Souza VC. Plantas visitadas por abelhas africanizadas em duas localidades do Estado de São Paulo. Sci Agric. 2001;58(2):41320.

31. Mendonça K, Marchini LC, Souza BA, AlmeidaAnacleto D, Moreti ACCC. Plantas apícolas de importância para Apis mellifera L. (Hymenoptera: Apidae) em fragmento de cerrado em Itirapina, SP. Neotrop Entomol. 2008;37(5):513-21.

32. Mendonça K, Marchini LC, Souza BA, AlmeidaAnacleto D, Moreti ACCC. Caracterização físicoquímica de amostras de méis produzidas por Apis mellifera L. em fragmento de cerrado no município de Itirapina, São Paulo. Cienc Rural. 2008;38(6):1748-53.

33. Tubélis A. Clima: fator que afeta a produção e qualidade da laranja. Laranja, Cordeirópolis. 1995;16(2):179-211.

34. Ribeiro RV, Machado EC, Brunini O. Ocorrência de condições ambientais para a indução do florescimento de laranjeiras no Estado de São Paulo. Rev Bras Frutic. 2006;28(2):247-53.

35. Rubink WL, Wilson WT, Resendez JJ, Maki DL. Pre-africanized Apis mellifera (Hymenoptera: Apidae) swarming dynamics in Northeastern Mexico and Southern Texas. J Kans Entomol Soc. 1990;63(2):288-97.

36. Schneider SS, Mcnally LC. Factors influencing seasonal absconding in colonies of the African honey bee, Apis mellifera scutellata. Insectes Sociaux. 1992;39(4):403-23.

37. Michener CD. The social behavior of the bees. Cambridge: Harvard University Press; 1974. 404 p.

38. Malerbo-Souza DT, Nogueira-Couto RH, Couto LA. Características das colônias de abelhas africanizadas (Apis mellifera L.), coletadas de alojamentos naturais em Jaboticabal, Estado de São Paulo. Acta Sci Anim Sci. 2002;24(4):863-7.

39. Southwick EE, Moritz RFA. Effects of meteorological factors on defensive behavior of honey bees. Int J Biometeorol. 1987;31(3):259-65.

40. Burril RM, Dietz A. The response of honey bees to variations in solar radiation and temperature. Apidologie. 1981;12(4):319-28.

41. Woyke J. Diurnal and seasonal variation in defensive behavior of African bees Apis mellifera adansonii in Ghana. Apidologie. 1992;23(4):31122.

42. Giorgini JF, Gusman AB. A importância das abelhas na polinização. In: Camargo JMF, editor. Manual de apicultura. Piracicaba: Editora Agronômica Ceres; 1972. p.155-214. 